\title{
Credit Quality of Trade Receivables and Its Impact on Cash Holdings and Firm Value
}

\author{
Guldehen Adiguzel ${ }^{1}$ \\ ${ }^{1}$ Department of Management, Bogazici University, Istanbul, Turkey \\ Correspondence: Guldehen Adiguzel, Department of Management, Bogazici Universitesi, IIBF, İşletme Bölümü, \\ 34342-Bebek, Istanbul, Turkey. Tel: 90-532-407-6710.
}

Received: February 2, 2021

Accepted: March 4, 2021

Online Published: March 10, 2021

doi:10.5430/ijba.v12n2p88

URL: https://doi.org/10.5430/ijba.v12n2p88

\begin{abstract}
This paper aims to define a variable that indicates the credit quality of trade receivables and test its impact on corporate cash holdings and corporate value. Based on a sample of publicly listed firms from the United States, we provide evidence that as the credit quality of trade receivables deteriorates, firms tend to keep higher levels of cash. This finding is in line with the precautionary motive for holding cash. Additionally, when trade receivables credit quality gets worse, corporate value is reduced. In all regressions, we treat trade receivable policy variables as endogenous because of concerns regarding omitted variables bias. Moreover, we provide the first large-sample US evidence about the negative and non-linear impact of investment in trade receivables on corporate value. We utilize system GMM in all estimations. The major contribution of this study to the accounting and trade credit literature is the introduction of a variable that aims to denote the credit quality of trade receivables and the empirical evidence about the impact of deterioration in trade receivables credit quality on cash holdings and corporate value. This study also extends the literature by delivering the first large-sample evidence for the US regarding the nature of the relationship between investment in trade receivables and corporate value.
\end{abstract}

Keywords: trade receivables, credit risk, cash holdings, corporate value

\section{Introduction}

Trade receivables (referred to as REC hereafter) represent a major investment of financial resources by businesses in the United States (US). At the aggregate level, listed non-financial firms in the US invest $11.9 \%$ of their assets in REC (Aktas, Croci, and Petmezas, 2015). Moreover, trade credit (TC) in the US economy represents more than 21\% of US GDP (Goncalves, 2016). Despite the decline in REC from 17.2\% of total assets in 1987 to $9.5 \%$ in 2015 for listed non-financial and non-utility US firms (Harris \& Roark, 2017), TC is still significant for the US economy both at the micro and macro levels.

This study contributes to the literature regarding the consequences of trade credit provision, which is still an under-researched field. Published work in this area has so far used the level of REC (scaled either by sales or by total assets) as the main explanatory variable of interest. However, models analyzing the consequences of TC supply should also factor credit risk of REC into the model specifications. Such credit risk arises from the probability of non-payment on time and/or in full. REC credit quality has become more critical for firms since the 2008 global financial crisis due to increased concerns about liquidity risk among treasury professionals (Ross, Westerfield, \& Jordan, 2012) and due to the swift reduction in dependence of firms on short-term credit lines from financial institutions (Sagner, 2014). In case of a customer default, suppliers are confronted with the risk of incurring large losses and more frequent shocks to operating cash flow, and this makes the credit quality of REC an important aspect of short-term financial management (Ross et al., 2012). As several funding sources, such as bank lines of credit and commercial paper, suddenly became unavailable after the 2008 financial crisis, REC credit quality requires high-level management attention because it affects the predictability, amount, and timeliness of cash inflows from customers.

This study extends the literature on the consequences of TC supply by defining an indicator variable that proxies the credit quality of receivables (TRQI) and by analyzing the direct impact this indicator has on cash holdings and corporate value (referred to as value hereafter) for a large sample of listed US firms for the first time. The findings of the analysis presented in this study are significant in guiding chief financial officers who are responsible for effective 
management of the firm's working capital (WCAP) in the prevailing business environment where converting increased sales into cash is becoming harder, capital expenditure is continuing to decline, and the cost of cash is increasing.

Based on previous studies in TC and accounting literature, we introduce TRQI, which takes the value 1 to indicate worsened credit quality of REC and 0 otherwise. Furthermore, we analyze the impact of TRQI on value and cash holdings. In the process of defining TRQI, we initially identified two possible indicators of deterioration in REC credit quality: average collection period trend and average collection period bucket migration, which we call primary indicators (Jacobson \& Schedvin, 2015; Jorion \& Zhang, 2009; Melumad \& Nissim, 2009). In the second phase, we identified three situations that may strengthen the possibility of a worsening REC credit quality when combined with the two primary indicators. These situations, which are called supporting indicators, are cash conversion cycle trends, profitability trends, and aggressive growth (Atanasova, 2012; Hill, Kelly, \& Venkiteshwaran, 2015; Molina \& Preve, 2009). Detailed definitions of these indicators are provided in Section 2. As a third step, we put these primary and secondary indicators together in three different combinations to come up with three versions of a composite indicator for REC credit quality (TRQI1, TRQI2, and TRQI3). Finally, we analyzed the impact of a deterioration in REC credit quality on cash holdings and value.

Firms with relatively higher levels of investment in REC may face cash flow shortages resulting from the inability of the client to honor its obligation on time and/or in full, which may impair the future cash flow generation capability of the supplier. Such firms are expected to retain more cash because cash acts as a cushion against future cash flow shortages (Lins, Servaes, \& Tufano, 2010). Suppliers with low REC credit quality aim to maintain their internal resource availability by tightening their cash policy. Therefore, we anticipate that as the credit quality of REC worsens, firms tend to hold more cash. This expectation is in line with Acharya, Davydenko, and Strebulaev (2012) in the sense that cash holdings respond to the possibility of a liquidity shortage.

Financially constrained buyers have the tendency and motivation to prefer extended TC terms to cash discounts (Atanasova, 2012). Additionally, customer defaults are more frequent, and loss given default is higher for suppliers that issue more TC (Jacobson \& Schedvin, 2015). Jorion and Zhang (2009) found that suppliers with larger credit exposures to their customers have an increased likelihood of corporate failure. Thus, as companies invest more in REC and offer longer trade terms to boost sales by capturing clients that are relatively more constrained, the suppliers' financial standing may be potentially impaired. Based on these, we anticipate that the worsened credit quality of REC has a negative impact on value.

Based on a sample of publicly traded, US-incorporated, non-financial, and non-utility firms from 2010 to 2016, we provide evidence that firms with worsened REC credit quality have the tendency to hold more cash. As the weakening of REC credit quality indicates increased credit risk, this finding aligns with the precautionary motive for holding excess cash. This situation triggers the firms' management to take precautionary action and the corporate cash level goes up. Deterioration in the credit quality of REC may also make it harder and more costly for the firm to access external capital, and this may be another reason why firms with inferior REC credit quality hold more cash. Considering the increased focus on liquidity after the 2008-2009 crisis (Ross et al., 2012), such a precautionary approach to cash management is highly sensible. Therefore, the excess cash held by firms with inferior REC credit quality acts as a cushion against a possible cash flow deficit in the future.

Our study also reveals new evidence regarding the value consequences of deterioration in REC credit quality. The findings of the multivariate regressions indicate that as the credit exposure of the supplier becomes riskier, firms experience a reduction in value. This implies that a strategy involving looser collection terms is far from achieving a reasonable balance between risk and return and thus diminishes value. Furthermore, we provide large-sample evidence for the US regarding the nature of the relationship between level of investment in REC and value, which is negative and non-linear.

For robustness purposes, we utilize alternative measures of value and cash holdings as dependent variables. Our conclusions remain the same when the alternative variables are used in regressions. We also test the components of TRQI individually. Findings of the multivariate regressions indicate that there is no consistent pattern regarding the direct impact of the individual components on cash holdings and value. However, when we combine these indicators of worsening REC credit quality under a composite indicator such as TRQI, we are able to identify the effect of deterioration in the credit quality of REC on value and cash holdings.

With this analysis, we aim to contribute to the growing literature on the consequences of TC supply in three major ways. First, to the best of our knowledge, no other study to date has defined an indicator of REC credit quality. Our second contribution is the analysis of the effect of deterioration in the credit quality of REC on cash holdings and 
value. Third, we provide the first US evidence regarding the negative and non-linear impact of investment in REC on value.

The rest of the paper is structured into four main sections. The next section provides a detailed description of TRQI and its components and also presents our hypotheses regarding the impact of worsened REC quality on cash holdings and value. In Section 3, we present the data; definitions of dependent, independent, and control variables; econometric model specifications; and estimation methodology. We deliver our empirical results in Section 4. Finally, Section 5 concludes the study.

\section{Trade Receivables Credit Quality Indicators}

The indicators of REC credit quality were developed by the author. TRQI is an indicator variable that takes the value 1 to indicate worsened credit quality of REC and 0 otherwise. Based on TC provision and accounting literature, we define two primary and three secondary indicators of worsened REC credit quality. A combination of two or more of these indicators forms the three versions of TRQI, whose detailed explanations are provided below. In Section 2.1, we explain the primary indicators, and in Section 2.2, definitions of three secondary indicators are presented. Finally, in Section 2.3, we provide our hypotheses regarding the impact of deterioration in REC quality on cash holdings and value.

\subsection{Primary Indicators}

One of the TRQI components (Component 1) is the trend in average collection period (ACP) (Note 1), which measures the average time it takes for the company to collect its REC from customers. An increase in ACP (from time t-1 to t) may be an indication of a change in credit policies (Melumad \& Nissim, 2009). Furthermore, if this trend continues for several years, it may be a signal for problems in collecting REC (Hill et al., 2015). Financially constrained buyers also have the tendency and motivation to prefer extended TC terms to cash discounts (Atanasova, 2012). This implies that the longer the collection terms are, the more constrained the portfolio of buyers is. Therefore, the credit exposure of the supplier becomes riskier as ACP goes up, and this implies worsened REC credit quality (Jacobson \& Schedvin, 2015). The upward trend in ACP may reflect either the suppliers' reluctance to cancel credit lines for their existing and/or seasoned customers whose credit quality has deteriorated over time, or the suppliers' passion and eagerness about growing sales through acquisition of new customers that are more constrained. Therefore, the ACP trend indicator takes the value 1 if the company's ACP has been going up for the last three years and 0 otherwise.

Another component of TRQI (Component 2) is the ACP bucket migration indicator. For the purpose of defining it, we categorize ACP into five buckets from 1 to 5 . A firm belongs to buckets 1,2, 3, and 4 if it has an ACP of less than 30,60, 90, and 120 days, respectively. Additionally, firms with an ACP of 120 days and higher are placed in bucket 5. Migration from a lower to a higher bucket represents an increase in ACP from year t-1 to t, such that bucket at time $t$ is above the bucket at time $t-1$. (Note 2) Therefore, the ACP bucket migration indicator takes the value 1 if the firm's REC aging structure migrated from a lower ACP bucket to a higher ACP bucket within time t-1 to $\mathrm{t}$, and 0 otherwise.

\subsection{Secondary Indicators}

We have also defined three situations that, when accompanied by the primary indicators, may strengthen the possibility of a deterioration in REC quality. Although the secondary indicators do not directly imply a worsening of REC quality when assessed on a stand-alone basis, they may support the possibility of deterioration if they appear at the same time as the primary indicators. The definitions of the secondary indicators are provided below.

The trend of the cash conversion cycle (CCC) (Note 3) constitutes another component of TRQI (Component 3). CCC proxies the efficiency of the WCAP process, which explains part of the variation in corporate profitability (Goddard, Tavakoli, \& Wilson, 2005). Firms are expected to adopt aggressive WCAP management strategies that would minimize CCC. However, simultaneous lengthening of ACP and CCC may indicate that the company's CCC is affected by the change in the trade receivable policy and that higher amounts of funds, which would otherwise be invested in positive NPV projects, are tied up to WCAP. If the company could offset the increase in ACP by shortening inventory days and/or lengthening payable days, CCC would remain unchanged. However, if the upward trend in ACP is accompanied by an upward trend in CCC, that would indicate a worsening of liquidity position due to deterioration in the credit quality of REC. Therefore, the CCC trend indicator takes the value 1 if the company's $\mathrm{CCC}$ has been going up for the last three years and 0 otherwise.

The profitability trend indicator is yet another component of TRQI (Component 4). TC literature presents evidence that firms with profitability problems extend REC collection terms to improve profitability (Molina \& Preve, 2009). 
If a company chooses to improve its profit margins through the acquisition of less creditworthy customers by offering longer payment terms, the overall credit risk of its receivables may worsen. Based on this reasoning, the profitability trend indicator takes the value 1 if the company's operating profit margin has been going up for the last three years and 0 otherwise.

Finally, to support the primary indicators of the worsened credit quality of REC, we introduce aggressive sales growth as another component of TRQI (Component 5). Given the empirical evidence regarding the positive impact of TC extension on sales growth (Yazdanfer \& Ohman, 2015) and firms' tendency to boost revenue through sales pull-in activities (Melumad \& Nissim, 2009), an indicator of aggressive sales growth would also signal worsened REC credit quality if it accompanies the upward trend and bucket migration in ACP (Harris \& Dudney, 2018; Hill, Kelly, \& Lockhart, 2012; Molina \& Preve, 2009). This indicator takes the value 1 if the company's sales growth rate (Note 4 ) is in the top 25 percentile within its industry for a given year and 0 otherwise.

Based on the above discussion, we define three alternative indicators for REC credit quality, which are calculated as follows:

TRQI $1=$ Component $1 *$ Component 2

TRQI2 $=$ Component $1 *$ Component $2 *$ Component 3

TRQI3 $=$ Component $1 *$ Component $2 *$ Component $3 *$ Component $4 *$ Components 5

As explained in detail above, Component 1 and Component 2 represent the primary indicators of weakened credit quality of REC, whereas Component 3, Component 4, and Component 5 represent the situations that support the possibility of deterioration in REC quality when accompanied by Component 1 and Component 2 .

\subsection{Hypotheses}

Cash holdings literature emphasizes the role of cash as a cushion against future cash flow shortages (Lins et al., 2010). Firms that have an upward trend in the average collection period are exposed to higher credit risk and thus have a higher probability of facing customer defaults (Jacobson \& Schedvin, 2015). This situation impairs the future cash flow generation capability of the supplier. Moreover, the upward trend in the average collection period can also restrict a firm's access to external capital and can make external financing more costly. These may force the firm to adapt a tighter cash policy. Therefore, the precautionary motive predicts that TRQI is positively related to cash holdings. We anticipate that suppliers with low REC credit quality aim to maintain their internal resource availability by tightening the cash policy so that they do not miss future investment opportunities. The expectation of a positive sign for TRQI in the cash holdings model also aligns with the findings documented by Acharya et al. (2012) that cash holdings respond to the possibility of a liquidity shortage. Therefore, our first hypothesis is:

H1: A deterioration of trade receivables credit quality has a positive impact on cash holdings.

Additionally, as TRQI is an indicator of bad (worsened) REC credit quality, we anticipate a negative relationship between TRQI and value, because a worsened REC credit quality may cause a reduction in value due to under-investment issues resulting mainly from bad debt losses and unexpected shocks to the operating cash flow process. Therefore, our second hypothesis is:

$\mathrm{H} 2$ : A deterioration of trade receivables credit quality has a negative impact on corporate value.

\section{Data and Methodology}

\subsection{Data}

For empirical analysis, we collected data from Bloomberg. The initial sample is composed of publicly traded, US-incorporated firms listed on NYSE, NASDAQ, and AMEX from 2010 to 2016. Firms operating in the financial sector and in utilities and firms that have negative revenue, missing REC, and missing SIC codes were excluded from the sample. Therefore, we conducted our analysis with a sample of 3,418 firms and 19,159 firm-year observations. However, as some measures were available only for some firms and as some variables (such as TRQI and cash flow volatility) were computed over a three-year period, the sample size used in the multivariate estimations is smaller. To minimize the influence of outliers, we winsorized all continuous variables at the top and bottom 1.

\subsection{Regression Model}

The first model aims to analyze the impact of TRQI on cash holdings and to test H1. The econometric model takes the following form: 


$$
\mathrm{CASH}_{\mathrm{i}, \mathrm{t}}=\beta_{0}+\beta_{1} \mathrm{CASH}_{\mathrm{i}, \mathrm{t}-1}+\beta_{2} \mathrm{TRQI}_{\mathrm{i}, \mathrm{t}}+\mathrm{Q}_{\mathrm{i}, \mathrm{t}} \beta_{3}+\text { Year Dummies }+\varepsilon_{\mathrm{i}, \mathrm{t}}
$$

The second model aims to analyze the direct effect of TRQI on value and to test $\mathrm{H} 2$. The econometric model is:

$$
\mathrm{TQ}_{\mathrm{i}, \mathrm{t}}=\beta_{0}+\beta_{1} \mathrm{TQ}_{\mathrm{i}, \mathrm{t}-1}+\beta_{2} \mathrm{TRQI}_{\mathrm{i}, \mathrm{t}}+\mathrm{X}_{\mathrm{i}, \mathrm{t}} \beta_{3}+\text { Year Dummies }+\varepsilon_{\mathrm{i}, \mathrm{t}}
$$

As we utilized system GMM (generalized method of moments) to estimate the above models, each model includes lagged values of CASH1 and TQ on the right-hand side of the respective equations. TRQI is the key variable of concern in both models. The models also include control variables $\left(\mathrm{Q}_{\mathrm{i}, \mathrm{t}}\right.$ and $\left.\mathrm{X}_{\mathrm{i}, \mathrm{t}}\right)$ and year dummies. The former controls for time-variant and firm-specific factors, whereas the latter controls for economic factors. $\varepsilon_{\mathrm{i}, \mathrm{t}}$ is the error term, where $\mathrm{i}$ and $\mathrm{t}$ indicate firm and year, respectively. Industry dummies were excluded from the regressions because the coefficients of industry dummies are neither individually nor jointly significant.

\subsection{Variables}

\subsubsection{Dependent Variables}

The following variables are used as two alternative proxies for corporate cash holdings in Model 1:

CASH1: Natural logarithm of (cash and marketable securities / total assets)

CASH2: Cash and marketable securities / total assets

Dependent variables of Model 2 are Tobin's Q (TQ) and enterprise value (EV). They are defined as:

TQ: (Market capitalization + total liabilities + preferred equity + minority interest) / total assets

EV: (Market value of equity + market value of debt—excess cash) / total assets

\subsubsection{Independent Variables}

The key independent variable of concern is TRQI, whose detailed explanation is provided in Section 2. We treat TRQI as an endogenous variable in all estimations, which we discuss in Section 3.4.

\subsubsection{Control Variables}

The following variables are included in Model 1 as control variables:

SIZE: $\ln$ (total assets) (Note 5)

LEV: Net debt / shareholders' equity

OCF: Cash flow from operations / total assets

MTB: (Book value of assets - book value of equity + market value of equity) / book value of assets

NWCAP: Net working capital / total assets (Note 6)

PPE: Plant, property, and equipment (net) / total assets

RD: Research and development expense / total assets

OCFVOL: STD (Operating cash flow) / (Average total assets - cash and marketable securities) (Note 7)

Similarly, the control variables of Model 2 are:

SIZE: $\ln$ (total assets)

LVRG: Total liabilities / total assets

PPE: Plant, property, and equipment (net) / total assets

GROWTH: Natural logarithm of $\left(\right.$ Sales $_{t} /$ Sales $\left._{\mathrm{t}-1}\right)$

ROA: Earnings before interest, taxes, depreciation, and amortization / total assets

The value model also incorporates RECTA (accounts receivable and notes receivable / total assets) as a control variable (Dary \& James, 2019; Martinez-Sola, Garcia-Teruel, \& Martinez-Solano, 2013; Wu, Rui, \& Wu, 2012). RECTA is a measure of a firm's level of investment in receivables, and we treat it as an endogenous variable in all estimations due to omitted variable bias concerns, which we discuss in Section 3.4.

TC literature lacks large-sample US evidence on the shape of the relationship between RECTA and value. To fill this gap, we test the non-linearity of the relationship between REC and value by adding RECTA ${ }^{2}$ as a control variable in the value model. Martinez-Sola et al. (2013) (Note 8) found a non-monotonic relation between investment in accounts receivable and value and concluded that the shape of the relationship is concave. In a recent study, Dary and James (2019) provide small-sample US evidence that RECTA is linearly associated with and has a positive 
impact on value. (Note 9) By exploring the shape of the relationship between value and TC supply, we provide the first large-sample US evidence regarding the impact of RECTA on value.

\subsection{Estimation Strategy}

We use system GMM (Note 10) (Blundell \& Bond, 1998) to estimate Model 1 and Model 2 so that we address the potential endogeneity issue related to TRQI and REC. A possible correlation between these variables and unobserved factors affecting either value or cash holdings may lead to endogeneity. Corporate governance, diversification, organizational structure, and product market dynamics are examples of unobserved non-financial factors that affect value and cash holdings (Berger \& Ofek, 1995; Barney, 1986; Denis, Denis, \& Yost, 2002; Hansen \& Wernerfelt, 1989; Harford, Mansi, \& Maxwell, 2008; Haushalter, Klasa, \& Maxwell, 2007; Hermalin \& Weisbach, 1991). These unobserved factors, which are captured by the error term, may lead to biased estimators. Thus, we avoid omitted variables bias by estimating our models through system GMM and also by treating REC and TRQI as endogenous rather than strictly exogenous. Accordingly, RECTA and TRQI are instrumented by their respective lag 2 in all estimations.

Arellano-Bond (AB) tests for serial correlation in the error term are used to assess model specification. $\mathrm{Ar}$ (1) denotes the $\mathrm{p}$-value of the first-order $\mathrm{AB}$ test, whereas $\operatorname{ar}(2)$ denotes the p-value of the second-order $\mathrm{AB}$ test. Furthermore, the validity of instruments is assessed by the Hansen test, whose p-value is reported in the tables regarding multivariate regression results for Models 1 and 2. Standard errors are robust to heteroscedasticity in all estimations. As standard errors from two-step GMM are downward biased (Arellano \& Bond, 1991), we utilize the one-step GMM estimator.

\section{Empirical Results}

\subsection{Descriptive Statistics and Correlation Matrix}

The descriptive statistics for the variables are given in Table 1 . The sample is mostly composed of firms operating in manufacturing and services industries, which make up 54\% and $20 \%$ of all observations, respectively. Firms operating in mining, retail, transportation, and communications industries make up $21 \%$ of the sample, whereas the remaining $5 \%$ of firms operate in construction, wholesale trade, and agriculture industries.

Table 1. Descriptive statistics

\begin{tabular}{lcccccc}
\hline Variable & $\mathrm{N}$ & Min & Median & Max & Mean & Std. Dev. \\
\hline \multicolumn{2}{l}{ Corporate Value } & Model Variables & & & & \\
\hline TQ & 15265 & 0.6476 & 1.6773 & 14.8687 & 2.2961 & 1.8039 \\
\hline EV & 15231 & 0.0405 & 1.2193 & 12.6623 & 1.7392 & 1.6127 \\
\hline RECTA & 16936 & 0.0000 & 0.0919 & 0.5169 & 0.1099 & 0.0982 \\
\hline SIZE & 16865 & 0.1781 & 6.2394 & 11.3467 & 6.1777 & 2.2053 \\
\hline LVRG & 15093 & 0.0492 & 0.5052 & 2.3745 & 0.5321 & 0.2997 \\
\hline PPE & 16982 & 0.0000 & 0.1316 & 0.9099 & 0.2183 & 0.2265 \\
\hline GROWTH & 13578 & -1.3838 & 0.0602 & 1.7777 & 0.0849 & 0.2988 \\
\hline ROA & 16708 & -2.9650 & 0.0911 & 0.4122 & -0.0231 & 0.3707 \\
\hline
\end{tabular}

\begin{tabular}{lllllll}
\hline \multicolumn{6}{l}{ Cash Holdings Model Variables } \\
\hline CASH1 & 16037 & -6.9875 & -1.8973 & -0.0147 & -2.0827 & 1.3824 \\
\hline CASH2 & 16038 & 0.0009 & 0.1500 & 0.9854 & 0.2506 & 0.2620 \\
\hline SIZE & 16865 & 0.1781 & 6.2394 & 11.3467 & 6.1777 & 2.2053 \\
\hline LEV & 15595 & -2.3163 & 0.0000 & 12.6452 & 0.2296 & 1.3420 \\
\hline OCF & 16861 & -2.4256 & 0.0726 & 0.3435 & -0.0157 & 0.3062 \\
\hline MTB & 13640 & 0.6707 & 1.6777 & 12.0752 & 2.2367 & 1.6158 \\
\hline
\end{tabular}




\begin{tabular}{lllllll}
\hline NWCAP & 15556 & -1.3107 & 0.0229 & 0.5249 & 0.0215 & 0.1993 \\
\hline PPE & 16982 & 0.0000 & 0.1316 & 0.9099 & 0.2183 & 0.2265 \\
\hline RD & 16365 & 0.0000 & 0.0089 & 1.5240 & 0.0905 & 0.1879 \\
\hline OCFVOL & 8923 & 0.0038 & 0.0353 & 0.5127 & 0.0600 & 0.0711 \\
\hline
\end{tabular}

\begin{tabular}{lllllll}
\hline \multicolumn{7}{l}{ Trade Receivables Credit Quality Indicators } \\
\hline TRQI1 & 8509 & 0.0000 & 0.0000 & 1.0000 & 0.0166 & 0.1277 \\
\hline TRQI2 & 7352 & 0.0000 & 0.0000 & 1.0000 & 0.0014 & 0.0369 \\
\hline TRQI3 & 7392 & 0.0000 & 0.0000 & 1.0000 & 0.0005 & 0.0233 \\
\hline
\end{tabular}

The correlation matrix for variables of Models 1 and 2 are presented in Tables 2 and 3, respectively. The correlations indicate that multicollinearity is not a concern. Additionally, VIF values, which are reported in the last columns of Table 2 and Table 3, are below the widely accepted critical VIF value of 5. Therefore, this also confirms the lack of multicollinearity among the variables for both models.

Table 2. Correlation matrix - Cash holdings model

\begin{tabular}{|c|c|c|c|c|c|c|c|c|c|c|c|c|}
\hline Variable & SIZE & LEV & OCF & MTB & NWCAP & PPE & $\mathrm{RD}$ & OCFVOL & TRQI1 & TRQI2 & TRQI3 & VIF \\
\hline SIZE & 1 & & & & & & & & & & & 1.56 \\
\hline LEV & $0 ., 3567 *$ & 1 & & & & & & & & & & 1.27 \\
\hline OCF & $0.5158^{*}$ & $0.2410^{*}$ & 1 & & & & & & & & & 2.79 \\
\hline MTB & $-0,2746^{*}$ & $-0,2589^{*}$ & $-0.2483^{*}$ & 1 & & & & & & & & 1.31 \\
\hline NWCAP & $0.1473 *$ & $0.0827 *$ & $0.3482 *$ & $-0.2723^{*}$ & 1 & & & & & & & 1.22 \\
\hline PPE & $0.2596^{*}$ & $0.2696^{*}$ & $0.2266^{*}$ & $-0.2123^{*}$ & $-0.0212 *$ & 1 & & & & & & 1.21 \\
\hline $\mathrm{RD}$ & $-0.4654^{*}$ & $-0.3448 *$ & $-0.7467 *$ & $0.3899^{*}$ & $-0.3834 *$ & $-0.2741^{*}$ & 1 & & & & & 2.96 \\
\hline OCFVOL & $-0.5073^{*}$ & $-0.3026^{*}$ & $-0.6210^{*}$ & $0.3258^{*}$ & $-0.2573^{*}$ & $-0.2353^{*}$ & $0.5940 *$ & 1 & & & & 1.90 \\
\hline TRQI1 & -0.0021 & 0.0071 & -0.0099 & 0.0051 & 0.0053 & $-0.0272 *$ & .0040 & -0.0125 & 1 & & & 1.00 \\
\hline TRQI2 & -0.0165 & -0.0048 & -0.0050 & 0.0129 & -0.0090 & -0.0174 & -0.0052 & -0.0043 & $0.2596^{*}$ & 1 & & 1.00 \\
\hline TRQI3 & $-0.0203^{*}$ & -0.0123 & -0.0077 & $0.0369 *$ & 0.0005 & $-0.0193^{*}$ & 0.0017 & 0.0046 & $0.0899 *$ & $0.3157^{*}$ & 1 & 1.00 \\
\hline
\end{tabular}

Note: $* \mathrm{p}<0.1$

Table 3. Correlation matrix - Corporate value model

\begin{tabular}{|c|c|c|c|c|c|c|c|c|c|c|}
\hline Variable & RECTA & SIZE & LVRG & PPE & GROWTH & ROA & TRQI1 & TRQI2 & TRQI3 & VIF \\
\hline RECTA & 1 & & & & & & & & & 1.16 \\
\hline SIZE & 0.0001 & 1 & & & & & & & & 1.47 \\
\hline LVRG & 0.0454* & $0.1881^{*}$ & 1 & & & & & & & 1.17 \\
\hline PPE & $-0.1802 *$ & $0.2596^{*}$ & $0.1127 *$ & 1 & & & & & & 1.18 \\
\hline GROWTH & 0.0046 & $-0.0542^{*}$ & $-0.0235^{*}$ & $-0.0892 *$ & 1 & & & & & 1.03 \\
\hline ROA & $0.2342 *$ & $0.5207^{*}$ & $-0.0514^{*}$ & $0.1978^{*}$ & $0.0269^{*}$ & 1 & & & & 1.48 \\
\hline TRQI1 & $0.0379^{*}$ & -0.0021 & 0.0016 & $-0.0272 *$ & $0.0207 *$ & -0.0010 & 1 & & & 1.00 \\
\hline TRQI2 & 0.0159 & -0.0165 & 0.0070 & -0.0174 & $0.0331^{*}$ & 0.0000 & $0.2596^{*}$ & 1 & & 1.00 \\
\hline TRQI3 & 0.0167 & $-0.0203^{*}$ & 0.0042 & -0.0193 & $0.0646^{*}$ & -0.0024 & $0.0899 *$ & $0.3157 *$ & 1 & 1.01 \\
\hline
\end{tabular}

Note: $* \mathrm{p}<0.1$ 


\subsection{Multivariate Regression Results}

\subsubsection{Impact of TRQI on Cash Holdings}

Multivariate regression results of the relationship between TRQI and cash holdings are presented in Table 4. The first and last three columns present the results of the estimations where dependent variables are CASH1 and CASH2, respectively.

Results regarding the coefficient of TRQI1 are mixed and are not statistically significant (columns 1 and 4). However, both TRQI2 and TRQI3 coefficients are positive and are statistically significant at the $1 \%$ level (columns 2, 3,5 , and 6). This suggests that firms whose REC credit quality is inferior take action toward increasing their cash holdings. This finding is in line with precautionary motives for holding excess cash in the sense that lengthening of ACP indicates increased credit risk. This situation triggers management of the firm to take precautionary action by increasing cash holdings to mitigate higher credit risk. Additionally, deterioration in the credit quality of REC may make it harder and/or more costly for the firm to access external capital. This may be another reason why firms with inferior REC credit quality hold more cash. Thus, TRQI2, and TRQI3 coefficients imply that firms take proactive action in case of deterioration in REC credit quality over time. Moreover, such proactive action may signal to the market that the firm is capable of managing this situation and that management has taken proper action to mitigate increased credit risk. Considering the increased focus on liquidity in the period following the 2008-2009 crisis, such a precautionary approach to cash management is highly sensible. Findings regarding TRQI2 and TRQI3 also align with Acharya et al. (2012) who report that cash holdings respond endogenously to the possibility of a liquidity shortage. Therefore, the excess cash held by firms with inferior REC credit quality acts as a cushion against a possible cash flow deficit in the future. These findings regarding TRQI2 and TRQI3 support our hypothesis (H1) that firms hold more cash as the credit quality of their REC worsens. The findings also align with US firms' increased concern about liquidity risk and their tendency to build up cash reserves following the global financial crisis in 2008 (Ross et al., 2012). Furthermore, control variables are statistically significant, and their signs are in line with the related literature (Bates, Kahle, \& Stulz, 2009; Opler, Pinkowitz, Stulz, \& Williamson, 1999).

Table 4. TRQI and cash holdings

\begin{tabular}{|c|c|c|c|c|c|c|}
\hline \multirow{2}{*}{ Variables } & \multicolumn{3}{|c|}{ Dependent Variable: CASH1 } & \multicolumn{3}{|c|}{ Dependent Variable: CASH2 } \\
\hline & (1) & (2) & (3) & (4) & (5) & (6) \\
\hline TRQI1 & -1.3844 & & & 0.2382 & & \\
\hline TRQI2 & & $1.1671 * * *$ & & & $0.5904 * * *$ & \\
\hline TRQI3 & & & $1.3790 * * *$ & & & $0.6272 * * *$ \\
\hline SIZE & $-0.0448 * * *$ & $-0.0449 * * *$ & $-0.0452 * * *$ & $-0.0059 * * *$ & $-0.0072 * * *$ & $-0.0068 * * *$ \\
\hline LEV & $-0.0016^{* * *}$ & $-0.0017 * * *$ & $-0.0017 * * *$ & $-0.0002 * * *$ & $-0.0002 * * *$ & $-0.0002 * * *$ \\
\hline OCF & $0.6361 * * *$ & $0.8938 * * *$ & $0.8831 * * *$ & $0.0871 * * *$ & $0.0991 * * *$ & $0.1013 * * *$ \\
\hline MTB & $0.0359 * * *$ & $0.0284 * * *$ & $0.0288^{* * *}$ & $0.0053^{* * *}$ & $0.0055^{* * *}$ & $0.0052 * * *$ \\
\hline NWCAP & $-0.8462 * * *$ & $-0.8803 * * *$ & $-0.8718 * * *$ & $-0.1423 * * *$ & $-0.1473 * * *$ & $-0.1422 * * *$ \\
\hline PPE & $-0.7063 * * *$ & $-0.7709 * * *$ & $-0.7537 * * *$ & $-0.0803 * * *$ & $-0.0891 * * *$ & $-0.0859 * * *$ \\
\hline $\mathrm{RD}$ & $1.0184 * * *$ & $1.4930 * * *$ & $1.4780 * * *$ & $0.1725^{* * *}$ & $0.2006^{* * *}$ & $0.1987 * * *$ \\
\hline OCFVOL & $1.2297 * * *$ & $1.6128 * * *$ & $1.5702 * * *$ & $0.3244 * * *$ & $0.2273^{* * *}$ & $0.2212 * * *$ \\
\hline Lagged CASH1/CASH2 & Included & Included & Included & Included & Included & Included \\
\hline Year Dummies & Included & Included & Included & Included & Included & Included \\
\hline Number of Obs. & 6270 & 5481 & 5501 & 6270 & 5481 & 5501 \\
\hline $\operatorname{ar}(1) p$-value & 0.000 & 0.000 & 0.000 & 0.000 & 0.000 & 0.000 \\
\hline $\operatorname{ar}(2) \mathrm{p}$-value & 0.733 & 0.930 & 0.878 & 0.597 & 0.435 & 0.264 \\
\hline Hansen p-value & 0.220 & 0.184 & 0.128 & 0.122 & 0.057 & 0.053 \\
\hline
\end{tabular}

Note: Statistical significance at $10 \%, 5 \%$, and $1 \%$ levels are denoted by $*, * *, * * *$, respectively. 
As an additional robustness check, we have also analyzed the impact of each TRQI component on cash holdings separately to identify their individual impacts, if any. In this analysis, five components of TRQI are included in the cash holdings model, each one at a time. The empirical results are presented in Table 5 for both CASH1 and CASH2 as dependent variables. The results indicate that none of the TRQI components had a significant impact on corporate cash levels consistently when tested individually. Finally, control variables continue to be statistically significant at the $1 \%$ level and have the same sign. The estimation results regarding the control variables are not tabulated due to space restrictions and are available upon request.

Table 5. TRQI components and cash holdings

\begin{tabular}{|c|c|c|c|c|c|c|c|c|c|c|}
\hline \multirow{2}{*}{ Variables } & \multicolumn{5}{|c|}{ Dependent Variable: CASH1 } & \multicolumn{5}{|c|}{ Dependent Variable: CASH2 } \\
\hline & (1) & (2) & (3) & (4) & (5) & (6) & (7) & (8) & (9) & (10) \\
\hline ACP Trend & $-0.2928 * *$ & & & & & 0.0144 & & & & \\
\hline (Component 1) & $(0.0245)$ & & & & & $(0.3942)$ & & & & \\
\hline ACP Bucket Migration & & 0.6105 & & & & & $0.2848 * *$ & & & \\
\hline (Component 2) & & $(0.4046)$ & & & & & $(0.0328)$ & & & \\
\hline CCC Trend & & & -0.0823 & & & & & -0.0031 & & \\
\hline (Component 3) & & & $(0.5148)$ & & & & & $(0.8502)$ & & \\
\hline Profitability Trend & & & & -0.0392 & & & & & -0.0154 & \\
\hline (Component 4) & & & & $(0.6923)$ & & & & & $(0.2684)$ & \\
\hline Aggressive Growth & & & & & -0.0556 & & & & & 0.0123 \\
\hline (Component 5) & & & & & $(0.7438)$ & & & & & $(0.6246)$ \\
\hline Controls & Included & Included & Included & Included & Included & Included & Included & Included & Included & Included \\
\hline Lagged CASH1/CASH2 & Included & Included & Included & Included & Included & Included & Included & Included & Included & Included \\
\hline Year Dummies & Included & Included & Included & Included & Included & Included & Included & Included & Included & Included \\
\hline No of Observations & 6270 & 5501 & 6264 & 6101 & 6369 & 6270 & 5501 & 6264 & 6101 & 6369 \\
\hline ar(1) p-value & 0.00 & 0.00 & 0.00 & 0.00 & 0.00 & 0.00 & 0.00 & 0.00 & 0.00 & 0.00 \\
\hline $\operatorname{ar}(2)$ p-value & 0.81 & 0.89 & 0.74 & 0.87 & 0.89 & 0.43 & 0.23 & 0.62 & 0.34 & 0.45 \\
\hline Hansen p-value & 0.37 & 0.04 & 0.40 & 0.36 & 0.31 & 0.05 & 0.06 & 0.10 & 0.08 & 0.02 \\
\hline
\end{tabular}

Note: Coefficient p-values are presented in parentheses. Statistical significance at $10 \%, 5 \%$, and $1 \%$ levels is denoted by $*, * *, * * *$, respectively

\subsubsection{Impact of TRQI on Corporate Value}

The results of multivariate regression of Model 2, which analyzes the impact of TRQI on value, are presented in Table 6. RECTA and TRQI proxy the quantity and quality of investment in REC, respectively. We treat RECTA and TRQI as endogenous variables due to omitted variable bias concerns. Results of the estimations, where the dependent variable is TQ, are presented in the first three columns, whereas the results of the estimations, where the dependent variable is $\mathrm{EV}$, are presented in the last three columns.

When the dependent variable is TQ, the coefficients of all TRQI indicators have a negative sign. TRQI2 and TRQI3 are statistically significant; however, TRQI1 is not statistically significant $(\mathrm{p}=0.154)$. The negative sign of TRQI coefficients implies that as the credit exposure of the supplier becomes riskier, the firm's value is reduced. Therefore, a strategy involving looser collection terms is far from achieving a reasonable balance between risk and return, and such a strategy diminishes value. Therefore, our hypothesis (H2) is supported by the empirical evidence. Additionally, coefficients of SIZE, LVRG, PPE, and ROA are statistically significant, and their signs align with those reported by similar studies in the corporate value literature. 
Table 6. TRQI and corporate value

\begin{tabular}{|c|c|c|c|c|c|c|}
\hline \multirow{2}{*}{ Variables } & \multicolumn{3}{|c|}{ Dependent Variable: TQ } & \multicolumn{3}{|c|}{ Dependent Variable: EV } \\
\hline & (1) & (2) & (3) & (4) & (5) & (6) \\
\hline TRQI1 & -2.5882 & & & $-3.7364 * *$ & & \\
\hline TRQI2 & & $-4.5694 * * *$ & & & $-5.0856 * * *$ & \\
\hline TRQI3 & & & $-3.4022 * *$ & & & $-3.8251 * * *$ \\
\hline RECTA & $-9.9095^{* *}$ & $-7.9952 * *$ & $-8.8093 * * *$ & -6.0426 & $-6.1094 * *$ & $-7.0895 * *$ \\
\hline RECTA $^{2}$ & $22.9634 * * *$ & $17.3907 * * *$ & $18.0814 * * *$ & $15.9413 * *$ & $13.6192 * *$ & $14.7972 * *$ \\
\hline SIZE & $-0.0662 * * *$ & $-0.0561 * * *$ & $-0.0621 * * *$ & $-0.0416^{*}$ & $-0.0428 * *$ & $-0.0485 * * *$ \\
\hline LVRG & $0.3148 * * *$ & $0.2130 * *$ & $0.2277 * *$ & $0.1970 * *$ & $0.1465 *$ & $0.1596 * *$ \\
\hline PPE & $-0.6335 * *$ & $-0.5155 * *$ & $-0.5746 * * *$ & -0.3585 & $-0.3485^{*}$ & $-0.4164 * *$ \\
\hline GROWTH & 0.1197 & 0.1052 & 0.0780 & 0.1448 & 0.1360 & 0.1185 \\
\hline $\mathrm{ROA}$ & 0.3911 & $0.3605 * *$ & $0.3845^{* *}$ & 0.2857 & $0.3875 * *$ & $0.4156 * *$ \\
\hline Lagged TQ/EV & Included & Included & Included & Included & Included & Included \\
\hline Year Dummies & Included & Included & Included & Included & Included & Included \\
\hline Number of Obs. & 6912 & 6097 & 6117 & 6923 & 6116 & 6136 \\
\hline $\operatorname{ar}(1) \mathrm{p}$-value & 0.000 & 0.000 & 0.000 & 0.000 & 0.000 & 0.000 \\
\hline $\operatorname{ar}(2) p$-value & 0.110 & 0.098 & 0.076 & 0.115 & 0.207 & 0.147 \\
\hline Hansen p-value & 0.054 & 0.149 & 0.086 & 0.030 & 0.063 & 0.031 \\
\hline
\end{tabular}

Note: Statistical significance at $10 \%, 5 \%$, and $1 \%$ levels are denoted by $*, * *, * * *$, respectively.

The robustness of the model is assessed by utilizing EV as an alternative measure of value (columns 4, 5, and 6). Consistent with the estimations with TQ, the results show a negative relationship between TRQI and EV. TRQI1 is statistically significant at the 5\% level, whereas TRQI2 and TRQI3 are statistically significant at the 1\% level. As for the control variables, SIZE and PPE continue to be statistically significant, and they both have a negative impact on enterprise value. Additionally, LVRG and ROA, which have a positive impact on enterprise value, also continue to be statistically significant.

As per the estimation results regarding the coefficients of RECTA, both linear and polynomial terms, we find that when companies invest more in receivables, value is reduced. This suggests that, despite several benefits of TC supply, the costs and potential risks involved in this type of investment outweigh the benefits. Thus, this finding supports our hypothesis that investment in REC is negatively associated with value. Additionally, the RECTA ${ }^{2}$ coefficient is positive and statistically significant, which implies that the relationship between RECTA and value is non-linear and concave. Therefore, the negative impact of a rise in RECTA has a more severe impact on corporate value for high-value firms compared to low-value companies. This constitutes the first large-sample evidence regarding the size and shape of the relationship between RECTA and value for listed US firms.

As an additional robustness check, we have also analyzed the individual impact of each TRQI component on value separately. In this analysis, five components of TRQI are included in the value model, each one at a time. As per the empirical results presented in Table 7, for both TQ (columns 1 through 5) and EV (columns 6 through 10) as dependent variables, TRQI components, other than profit margin trend, do not have a significant impact on value when tested individually. However, when these components are combined to represent the credit quality of REC on a company's books, their collective impact on value is statistically significant and intuitively reasonable. Finally, control variables are statistically significant at the $1 \%$ level and have the same sign. The estimation results regarding the control variables are not tabulated due to space restrictions and are available upon request. 
Table 7. TRQI components and corporate value

\begin{tabular}{|c|c|c|c|c|c|c|c|c|c|c|}
\hline \multirow{2}{*}{ Variables } & \multicolumn{5}{|c|}{ Dependent Variable: TQ } & \multicolumn{5}{|c|}{ Dependent Variable: EV } \\
\hline & (1) & (2) & (3) & (4) & (5) & (6) & (7) & (8) & (9) & (10) \\
\hline ACP Trend & -0.1242 & & & & & -0.2544 & & & & \\
\hline (Component 1) & $(0.4491)$ & & & & & $(0.1018)$ & & & & \\
\hline ACP Bucket Migration & & -0.4559 & & & & & 0.2382 & & & \\
\hline (Component 2) & & $(0.7031)$ & & & & & $(0.8186)$ & & & \\
\hline CCC Trend & & & -0.1929 & & & & & $-0.2898^{*}$ & & \\
\hline (Component 3) & & & $(0.2528)$ & & & & & $(0.0611)$ & & \\
\hline Profit Margin Trend & & & & $0.3921^{* *}$ & & & & & $0.3230^{* *}$ & \\
\hline (Component 4) & & & & $(0.0287)$ & & & & & $(0.0287)$ & \\
\hline Aggressive Growth & & & & & 0.0449 & & & & & 0.0601 \\
\hline (Component 5) & & & & & $(0.2309)$ & & & & & $(0.1002)$ \\
\hline Controls & Included & Included & Included & Included & Included & Included & Included & Included & Included & Included \\
\hline Lagged TQ/EV & Included & Included & Included & Included & Included & Included & Included & Included & Included & Included \\
\hline Year Dummies & Included & Included & Included & Included & Included & Included & Included & Included & Included & Included \\
\hline No of Observations & 6912 & 6117 & 8392 & 6755 & 8589 & 6923 & 6136 & 8408 & 6770 & 8602 \\
\hline $\operatorname{ar}(1) p$-value & 0.00 & 0.00 & 0.00 & 0.00 & 0.00 & 0.00 & 0.00 & 0.00 & 0.00 & 0.00 \\
\hline $\operatorname{ar}(2) p$-value & 0.15 & 0.06 & 0.41 & 0.08 & 0.50 & 0.21 & 0.12 & 0.80 & 0.15 & 0.53 \\
\hline Hansen p-value & 0.04 & 0.01 & 0.15 & 0.11 & 0.39 & 0.01 & 0.01 & 0.17 & 0.02 & 0.40 \\
\hline
\end{tabular}

Note: p-values of TRQI components are presented in parentheses. Statistical significance at $10 \%, 5 \%$, and $1 \%$ levels is denoted by $*, * *, * * *$, respectively.

\section{Conclusion}

Increased concerns about liquidity risk among treasury professionals at North American companies and rapidly declining reliance of businesses on short-term credit lines from banks and other sources after the 2008 global financial crisis imply that not only the level of firms' investment in REC but also the credit quality of REC has become more critical for firms. Therefore, management of REC credit quality is a crucial aspect of short-term finance, as quality issues regarding a firm's REC may well affect the predictability, amount, and timeliness of cash inflows from customers. However, one question that has not been examined before is if and how REC credit quality affects cash holdings and the value of firms. So far, there has been no attempt in the related literature to define an indicator of REC credit quality. Furthermore, there is a gap in the existing literature regarding large-sample US evidence on the value consequences of investment in REC.

The purpose of this study was to define a measure of REC credit quality and analyze the effects of deterioration in the credit quality of REC on corporate cash holdings and value using a panel of US listed, non-financial, and non-utility firms. We, therefore, developed a variable by combining possible indicators of worsened REC credit quality (historical trend of REC collection period, changes in REC aging profile) with situations that could strengthen the possibility of a worsening in REC quality when they accompany the two primary indicators. These situations, which we call secondary indicators, are the historical trend of the cash conversion cycle, the historical trend of profit margin, and the firm's growth rate. We further analyzed the cash holdings and value consequences of deterioration in REC credit quality.

As per the empirical results of the multivariate regression analysis, deterioration in the credit quality of REC had a positive impact on cash holdings and a negative impact on value. Additionally, both of these effects were statistically significant. Our findings align with the findings of Harris and Roark (2017), who provided evidence that increases in cash flow risk were a major factor explaining the decline in aggregate TC levels across US firms. Therefore, deterioration in REC credit quality may lead to unexpected shocks to operating cash flow and may create further volatility. This helps explain the negative impact of deterioration in REC credit quality on value as well as the precautionary excess cash held by companies that experience a decline in the credit quality of REC over time. We also provided the first large-sample evidence regarding listed non-financial US firms that level of investment in REC is negatively associated with value and this relationship is non-linear.

With this study, we contribute to accounting, trade credit, and cash holdings literature in several ways. To the best of our knowledge, this is the first attempt to define an indicator of REC credit quality. Furthermore, this study analyzes 
the impact of deterioration in REC credit quality on both cash holdings and value. Additionally, we are the first to investigate the nature of the relationship between a firm's level of investment in REC and value for a large sample of US firms. Therefore, we present strong evidence that the credit quality of trade receivables has liquidity and performance-related consequences. The establishment of a balanced credit risk policy and its proper implementation should be a priority for any chief financial officer of non-financial firms. What matters eventually is not only how much a firm invests in trade receivables but also the credit quality of such investment.

Research in this area may be extended further by capturing both publicly quoted companies and privately held firms, which would allow us to execute a comparative analysis of how the trade receivable policy of firms impacts their value and cash holdings. Finally, similar analysis covering emerging markets may well provide valuable insights into the role of trade credit in countries with relatively less developed capital markets.

\section{References}

Acharya, V., Davydenko, S. A., \& Strebulaev, I. A. (2012). Cash holdings and credit risk. The Review of Financial Studies, 25(12), 3572-3609. https://doi.org/10.1093/rfs/hhs106

Aktas, N., Croci, E., \& Petmezas, D. (2015). Is working capital management value-enhancing? Evidence from firm performance and investments. Journal of Corporate Finance, 30, 98-113. https://doi.org/10.1016/j.jcorpfin.2014.12.008

Arellano, M., \& Bond, S. (1991). Some tests of specification for panel data: Monte Carlo evidence and an application to employment equations. The Review of Economic Studies, 58(2), 277-297. https://doi.org/10.2307/2297968

Atanasova, C. (2012). How do firms choose between intermediary and supplier finance?. Financial Management, 4l(1), 207-228. https://doi.org/10.1111/j.1755-053X.2012.01183.x

Barney, J. B. (1986). Organizational culture: Can it be a source of sustained competitive advantage?. Academy of Management Review, 11(3), 656-665. https://doi.org/10.5465/amr.1986.4306261

Bates, T., Kahle, K., \& Stulz, R. (2009). Why do US firms hold so much more cash than they used to?. Journal of Finance, 64(5), 1985-2021. https://doi.org/10.1111/j.1540-6261.2009.01492.x

Berger, P. G., \& Ofek, E. (1995). Diversification's effect on firm value. Journal of Financial Economics, 37(1), 39-65. https://doi.org/10.1016/0304-405X(94)00798-6

Blundell, R., \& Bond, S. (1998). Initial conditions and moment restrictions in dynamic panel models. Journal of Econometrics, 87(1), 115-143. https://doi.org/10.1016/S0304-4076(98)00009-8

Dary, S., \& James Jr, H. (2019). Does investment in trade credit matter for profitability? Evidence from publicly listed agro-food firms. Research in International Business and Finance, 47, 237-250. https://doi.org/10.1016/j.ribaf.2018.07.012

Denis, D. J., Denis, D. K., \& Yost, K. (2002). Global diversification, industrial diversification, and firm value. Journal of Finance, 57(5), 1951-1980. https://doi.org/10.1111/0022-1082.00485

Goddard, J., Tavakoli, M., \& Wilson, J. O. S. (2005). Determinants of profitability in European manufacturing and services: Evidence from a dynamic panel model. Applied Financial Economics, 15(18), 1269-1282. https://doi.org/10.1080/09603100500387139

Goncalves, A. B. (2016). Three essays on trade credit and market power. Ph.D. thesis. Retrieved from http://hdl.handle.net/10438/17241

Hansen, G. S., \& Wernerfelt, B. (1989). Determinants of firm performance: The relative importance of economic and organizational factors. Strategic Management Journal, 10(5), 399-411. https://doi.org/10.1002/smj.4250100502

Harford, J., Mansi, S., \& Maxwell, W. (2008). Corporate governance and firm cash holdings in the US. Journal of Financial Economics, 87(3), 535-555. https://doi.org/10.1016/j.jfineco.2007.04.002

Harris, C., \& Dudney, D. (2018). Securitization, trade credit and the nature of goods. Journal of Accounting \& Finance, 18(2), 47-71.

Harris, C., \& Roark, S. (2017). Exploring the decline in trade credit investment. Managerial Finance, 12(43), 1375-1391. https://doi.org/10.1108/MF-04-2017-0140 
Haushalter, D., Klasa, S., \& Maxwell, W. (2007). The influence of product market dynamics on a firm's cash holdings and hedging behavior. Journal of Financial Economics, 84(3), 797-825. https://doi.org/10.1016/j.jfineco.2006.05.007

Hermalin, B., \& Weisbach, M. (1991). The effects of board composition and direct incentives on firm performance. Financial Management, 20(4), 101-112. https://doi.org/10.2307/3665716

Hill, M., Kelly, G., \& Lockhart, G. (2012). Shareholder returns from supplying trade credit. Financial Management, 4l(1), 255-280. https://doi.org/10.1111/j.1755-053X.2012.01198.x

Hill, M., Kelly, G., \& Venkiteshwaran, V. (2015). On the diminishing return to trade credit. The Journal of Financial Research, 38(3), 305-317. https://doi.org/10.1111/jfir.12061

Jacobson, T., \& Schedvin, E. (2015). Trade credit and the propagation of corporate failure. Econometrica, 83(4), 1315-1371. https://doi.org/10.3982/ECTA12148

Jorion, P., \& Zhang, G. (2009). Credit contagion from counterparty risk. The Journal of Finance, 64(5), 2053-2087. https://doi.org/10.1111/j.1540-6261.2009.01494.x

Lins, K., Servaes, H., \& Tufano, P. (2010). What drives corporate liquidity? An international survey of cash holdings and lines of credit. Journal of Financial Economics, 98(1), 160-176. https://doi.org/10.1016/j.jfineco.2010.04.006

Martinez-Sola, C., Garcia-Teruel, P., \& Martinez-Solano, P. (2013). Trade credit policy and firm value. Applied Economics, 45(2), 161-170. https://doi.org/10.1111/j.1467-629X.2012.00488.x

Melumad, N., \& Nissim, D. (2009). Line-item analysis of earnings quality. Foundations and Trends in Accounting, $3(2-3), 87-221$.

Molina, C. A., \& Preve, L. A. (2009). Trade receivables policy of distressed firms and its effect on the costs of financial distress. Financial Management, 38(3), 663-686. https://doi.org/10.1111/j.1755-053X.2009.01051.x

Opler, T., Pinkowitz, L., Stulz, R., \& Williamson, R. (1999). The determinants and implications of corporate cash holdings. Journal of Financial Economics, 52(1), 3-46. https://doi.org/10.1016/S0304-405X(99)00003-3

Roodman, D. (2009). How to do xtabond2: An introduction to difference and system GMM in Stata. Stata Journal, 9(1), 86-136. https://doi.org/10.1177/1536867X0900900106

Ross, S. A., Westerfield, R. W., \& Jordan, B. D. (2012). Fundamentals of corporate finance (International ed.). New York, NY: McGraw Hill.

Sagner, J. (2014). Working capital management: Applications and case studies. Hoboken, New Jersey: John Wiley \& Sons, Inc.

Wu, W., Rui, O., \& Wu, C. (2012). Trade credit, cash holdings, and financial deepening: Evidence from a transitional economy. Journal of Banking and Finance, 36, 2868-2883. https://doi.org/10.1016/j.jbankfin.2011.04.009

Yazdanfer, D., \& Ohman, P. (2015). The impact of credit supply on sales growth: Swedish evidence. International Journal of Managerial Finance, 11(3), 329-340.

\section{Notes}

Note 1 . ACP is calculated by dividing year-end net trade receivables by daily sales figure.

Note 2. In the aging report, total amount of unpaid/overdue invoices are listed by groupings of days in the form of 30-day buckets (Sagner, 2014), which represent the length of time an invoice has been outstanding.

Note 3. CCC is calculated by adding the average age of inventory (ending inventory / cost of revenue *365) and ACP and then subtracting the average payment period (accounts payable / annual purchases *365) from this sum.

Note 4. Natural logarithm of ( sales $_{\mathrm{t}} /$ sales $_{\mathrm{t}-1}$ ).

Note 5. "ln" stands for natural logarithm.

Note 6. Net working capital equals current assets minus current liabilities minus cash and marketable securities.

Note 7. Standard deviation and net asset averages are calculated over a period of 4 years.

Note 8. Evidence is based on a small sample of 54 Spanish listed firms for the period from 2001 to 2007. 
Note 9. Based on a sample of 204 agro-food firms engaged in the food and drinks businesses (manufacturing and non-manufacturing) over the period 2001-2014.

Note 10. We use xtabond2 module in Stata (Roodman, 2009) to execute system GMM.

\section{Copyrights}

Copyright for this article is retained by the author(s), with first publication rights granted to the journal.

This is an open-access article distributed under the terms and conditions of the Creative Commons Attribution license (http://creativecommons.org/licenses/by/4.0/). 